\title{
REACTION OF HUMAN BLOOD-FORMING TISSUES TO CHRONIC BENZENE EXPOSURE
}

BY

\author{
V. H. BOWERS \\ From the Royal Lancaster Infirmary
}

(RECEIVED FOR PUBLICATION, OCTOBER 3, 1946)

For many years it has been generally believed that the clinical manifestations of chronic benzene poisoning in man are due to an aplasia of the bloodforming tissue in the bone marrow. This concept arose out of the pioneer experimental and clinical work of Santesson (1897) and of Selling $(1910,1916)$, and it is still widely held at the present time. It is the purpose of this paper to draw attention to the literature, which suggests that the reaction of the blood-forming tissues to benzene exposure is, in fact, much more varied, and to describe the case which first brought this literature to our notice. This subject is of some importance at the present time, when sternal puncture techniques are becoming increasingly used in the diagnosis of cases of intractable anaemia. In some of these cases failure correctly to attribute the cause to benzene exposure may stand in the way of measures being applied to reduce the hazard in the occupation responsible, and may also prevent a proper claim for compensation being established.

\section{Review of the Literature}

In a general review of the subject in 1931, Hamilton pointed out that the prevailing concept of chronic benzene poisoning in man was based very largely on the results of acute benzene poisoning in animals. That the conditions were not strictly comparable was suggested by the fact that animals usually showed a severe granular leucopenia with little or no anaemia, whereas anaemia is usually the most striking feature in man. Hamilton noted the paucity of recorded studies of human material, and drew attention to the variety of changes which had been reported as occurring in the blood-forming tissues. Some cases showed extensive extramedullary haemopoiesis: three cases had hyperplastic bone marrows. Hamilton concluded that a much wider concept of the results of benzene poisoning in man would have to be adopted as knowledge of the condition increased. It was not until 1939, however, that Mallory and others published an article which suggested that hyperplasia of the bone marrow with extensive extramedullary haemopoiesis might be quite a common result of chronic benzene poisoning in man. They made a study which included the histology of material from 19 cases, 14 being autopsies and 5 biopsies. Of these cases, 9 showed frank hyperplasia of the bone marrow, and in 5 the hyperplasia was described as marked. Only 6 showed hypoplasia, and no case of complete aplasia was seen. Haemopoiesis was frequently found in the liver, spleen, and lymphnodes: and the liver and spleen were often greatly enlarged. In some cases the haemopoiesis was grossly atypical, and histological pictures resembling 'Hodgkin's sarcoma' were seen. There was a general parallelism in the degree and type of change found in the bone marrow and spleen of any one case. These authors give a full review of the literature, and an extensive bibliography from which the earlier references in this paper were obtained. They point out that our prevailing conceptions have been based to a large degree on studies of the changes in the peripheral blood which have been shown by a number of authors to furnish an unreliable index of the state of the bone marrow (Blumer, 1905; Thompson and others, 1935; Rhoades and Miller, 1938). Reference is made to 5 cases of benzene poisoning with hyperplastic bone marrow previously reported in the literature, and to a number of cases with various types of leukaemia. Of the 19 cases described by Mallory and others, 1 was an acute myeloid leukaemia with a typical leukaemic nodule in the liver, 1 a lymphoblastic leukaemia, and 1 an aleukaemic leukosis.

In 1940 Jackson and others described a syndrome under the title of 'agnogenic myeloid metaplasia' characterized by weakness, abdominal distress, and a haemorrhagic tendency, with progressive enlargement of the spleen, a moderately elevated or slightly depressed white cell count, and the constant presence of immature red and white cells in the peripheral blood. The spleens of all 10 cases described showed marked myeloid metaplasia, while the bone marrows were variously fibrotic, hyperplastic (1 case), aplastic, or normal. In no case was the marrow suggestive of leukaemia. Three of these patients were submitted to 
splenectomy and all died within a year of operation; because of this the authors urge the importance of recognizing the condition as a distinct entity. The term 'agnogenic' was used to suggest ignorance of the cause of the condition.

Later Rawson and others (1941), noting the similarity of the histological findings and certain clinical features to those found in chronic benzene poisoning, made a special inquiry into the occupational histories of the 6 cases then attending their clinic diagnosed as agnogenic myeloid metaplasia. All 6 gave histories of many years' exposure to various industrial solvents, 3 to benzene, 1 to carbon tetrachloride, 1 to ' high test gasoline,' and 1 to a paint remover of unstated composition.

\section{Case Report}

The accounts of the occupational history and of the onset of the illness are drawn partly from the depositions of witnesses taken on oath at the inquest, copies of which were kindly sent to me by the coroner, Mr. G. F. E. Wilson, and partly from the history given by the patient when admitted to hospital. There are no major points of difference in these sources of information: where the exact dates differ, the depositions have been assumed to be correct.

\section{Occupational History}

The patient, a married man of 36 years, in 1937 began work supervising machines which spread cellulose resin in solvents on to cotton textiles. From 1937 until 1940 the solvent contained four parts pure benzene and one part industrial methylated spirits. In 1940 pure benzene became unobtainable, and benzol 90's (mainly benzene with less than 2 per cent. toluene and a trace of thiophene) was used as a substitute. From September, 1941, solutions of chlorinated rubber in benzol 90 's were used aiso, and this formed a large proportion of the material with which he worked until April, 1942. After that date nitrocellulose solutions were spread intermittently in a solvent made up of benzol 90's five parts, mixed with methyl acetone three parts (methyl acetone consists of methyl alcohol, acetone, and methyl acetate, equal parts of each). Concurrently with the above benzene solvent used since 1942, cellulose acetate in methyl acetone solution was used in increasing proportions of the work, and the benzol preparations were used in decreasing amounts until the present time. The patient was thus exposed to benzene solvents constantly from 1937 to 1942 (5 years) and intermittently from 1942 until the onset of his illness in December, 1944 ( 2 years 8 months).

The spreading machines were fitted with hoods and ducts connecting with a suction fan for solvent recovery, and the workroom was said to be large and well-ventilated through wide doors and the roof. The patient was not required to wear a respirator when employed at his usual job. The widow stated that when he began to lose his appetite he told her,. 'It's that benzene on my stomach.' She had frequently smelt benzene from his clothes, and even when he' had changed his clothes she noticed the same smell in his breath. He had frequently complained about the benzene, and had described the workshop as 'laden with benzene fumes' in the period before 1942 .

\section{History of Onset of Illness}

In December, 1944, the patient had an attack of tonsillitis and pharyngitis, and since then had suffered a gradually increasing tiredness, aching in the calves, palpitations, and throbbing in the head. At the end of January, 1945, his wife noticed that he began to lose his colour and energy. He became irritable and iost his appetite. At the end of May, 1945, his movements became difficult and his wife persuaded him to see his doctor, who told him that he had anaemia. A blood count on June 12, 1945, gave the following results: Hb 40 per cent. ( 5.9 g. per 100 c.cm.); red blood cells, $1,600,000$ per c.mm.; colour index, 1.25; white blood cells, 2,600 per c.mm.; neutrophil polymorphs 7 per cent.; lymphocytes 78 per cent.; monocytes 1 per cent.; eosinophils 1 per cent.; metamyelocytes 12 per cent.; myeloblasts 1 per cent. The film showed slight anisocytosis and polychromasia, with a small number of stipple-cells.

He was treated with anahaemin, hog stomach extract, iron, and dilute hydrochloric acid, and made no progress. On July 9,1945 , his count was: $\mathrm{Hb} 30$ per cent. (4.4 g. per 100 c.cm.); red blood cells $1,200,000$ per c.mm. On July 11 he was admitted to hospital for further investigation and treatment.

\section{Clinical State on Admission}

The following information has been abstracted from the notes written by Dr. C. Atkinson.

Present Complaint.- He complained of tiredness and weakness (before coming to hospital he had become too weak to shave). Appetite was good but soon satisfied. He had lost $8 \mathrm{lb}$. in the last six months. He had had a slight cough during the past three days. There was no dyspnoea. Micturition and bowel action were normal, and there were no haemorrhoids.

Previous History.-The doctor who examined him for an insurance policy shortly after he began his employment in 1937 remarked on his fine physical standard. The patient had pneumonia in 1942.

Family History.-Both parents were living and well. His wife and three children were all living and well.

Clinical Examination.-The patient was very pale, edentulous, and had an area of herpes labialis which had been present three days. The tongue was slightly furred. The pulse was regular, rate 94 , 'water-hammer' type, the blood pressure 150/50, the apex beat not localized, and there was a soft systolic murmur at the apex. The chest was barrel-shaped with equal expansion on the two sides, and very resonant everywhere; there was prolonged expiration and râles and rhonchi were heard in all regions. The abdomen felt 'doughy'; there was no rigidity and no tenderness. The spleen was thought to be felt one finger's breadth below the costal margin, but not with any certainty. The liver was not palpable. No palpable lymph nodes were found, and no abnormal signs in the nervous system. 
The patient was given one pint of stored blood on July 12, 1945, and another on July 20.

\section{Special Investigations}

On July 24, 1945, the blood picture was: Hb 40 per cent. (5.9 g. per 100 c.cm.); red blood cells, 2,000,000 per c.mm.; colour index 1.0; nucleated cell count 3,000 per c.mm.; neutrophil polymorphs 4 per cent.; lymphocytes 81 per cent.; monocytes 2 per cent.; eosinophils 1 per cent.; basophils 1 per cent; metamyelocytes 3 per cent.; myelocytes 1 per cent.; myeloblasts 2 per cent.; normoblasts 5 per cent. The film showed slight anisocytosis and polychromasia. The mean corpuscular haemoglobin concentration (M.C.H.C.) was 31 per cent. (normal 32 to 38 per cent.). The mean corpuscular volume (M.C.V.) was $95 \mathrm{cu}$. microns (normal 78 to $94 \mathrm{cu}$. microns). The serum bilirubin was less than $0.1 \mathrm{mg}$. per $100 \mathrm{c.cm}$. The fractional test meal showed free $\mathrm{HCl}$ in most specimens with $40 \mathrm{c.cm}$. N/10 $\mathrm{HCl}$ per cent. of the fasting juice, falling off to zero in the last two specimens: no histamine was used. The blood Wassermann reaction was negative. On July 7, 1945, platelets numbered 85,000 per c.mm. On July 18, 1945, $\boldsymbol{x}$ ray of the chest showed moderate generalized peribronchial thickening with some degree of bronchitis; the apices were clear, the air entry was good, and no other changes were seen. The urinary sulphates were not investigated, seven months having elapsed since his last exposure to benzene.

A sternal puncture was performed on August 21, 1945, and again on December 21, 1945 . The smears and cell

TABLE 1

\begin{tabular}{|c|c|c|c|}
\hline \multirow{2}{*}{ Cells } & \multicolumn{2}{|c|}{ Patient } & \multirow{2}{*}{$\underset{C}{\text { Normal }}$} \\
\hline & $\underset{21.8 .45}{\mathrm{~A}}$ & $\stackrel{\mathrm{B}}{21.12 .45}$ & \\
\hline $\begin{array}{l}\text { Total nucleated cells } \\
\text { per c.mm. }\end{array}$ & 300,000 & 300,000 & $25,000-100,000$ \\
\hline $\begin{array}{l}\text { Differential nucle- } \\
\text { ated cell count } \\
\text { percentages: }\end{array}$ & & & i \\
\hline $\begin{array}{l}\text { Neutrophil: } \\
\text { polymorphs } \\
\text { metamyelocytes } \\
\text { myelocytes }\end{array}$ & $\begin{array}{l}0 \cdot 25 \\
1 \cdot 0 \\
10 \cdot 0\end{array}$ & $\begin{array}{l}1 \cdot 75 \\
0 \cdot 5 \\
7 \cdot 5\end{array}$ & $\begin{array}{r}22 \cdot 0-50 \cdot 0 \\
2 \cdot 5-12 \cdot 0 \\
2 \cdot 0-8 \cdot 0\end{array}$ \\
\hline $\begin{array}{l}\text { Eosinophil: } \\
\text { polymorphs } \\
\text { myelocytes }\end{array}$ & $\begin{array}{l}0.25 \\
6 \cdot 25\end{array}$ & $\begin{array}{l}0 \\
1 \cdot 25\end{array}$ & $\begin{array}{l}0-4 \cdot 0 \\
0-3 \cdot 5\end{array}$ \\
\hline Basophil myelocytes & 0.25 & 0 & - \\
\hline $\begin{array}{l}\text { Premyelocytes } \\
\text { Myeloblasts }\end{array}$ & $\begin{array}{l}6 \cdot 5 \\
5 \cdot 5\end{array}$ & $\begin{array}{l}6 \cdot 75 \\
7 \cdot 25\end{array}$ & $\begin{array}{r}0.5-5 \cdot 0 \\
0-2 \cdot 5\end{array}$ \\
\hline $\begin{array}{l}\text { Lymphocytes } \\
\text { Monocytes }\end{array}$ & $11 \cdot 75$ & $\begin{array}{l}7 \cdot 0 \\
0 \cdot 75\end{array}$ & $\begin{array}{c}5 \cdot 0-20 \cdot 0 \\
0-5 \cdot 0\end{array}$ \\
\hline Normoblasts & $14 \cdot 25$ & $25 \cdot 75$ & $7 \cdot 0-19 \cdot 0$ \\
\hline Erythroblasts & $25 \cdot 75$ & $27 \cdot 5$ & $2 \cdot 0-7 \cdot 0$ \\
\hline Megaloblasts & $17 \cdot 5$ & $14 \cdot 0$ & $0-4 \cdot 0$ \\
\hline Megakaryocytes & $0 \cdot 25$ & 0 & - \\
\hline Turk cells & 0.5 & 0 & - \\
\hline
\end{tabular}

Ratio:

myeloid cells

$\begin{array}{llll}\text { nucleated erythroid } & 0.45 & 0.37 & 2.0-8.0\end{array}$

counts gave results as in Table 1 (terininology of Doan Sabin and Cunningham; normal values from Whitby and Britton's Disorders of the Blood, fourth edition). These counts both show a marrow with marked hyperplasia of the erythroid elements, with failure of maturation of both erythroid and myeloid cells. Mitoses were infrequent. On each occasion 400 cells were counted.

\section{Treatment}

During his three months' stay in hospital, he received at various times courses of full doses of the following preparations: anahaemin, 'gastrexo', ferrous sulphate tablets, with dilute hydrochloric acid, ascorbic acid (orally), and 'adexolin'. He also had an eight-day course of pentose nucleotide $10 \mathrm{c.cm}$. intramuscularly twice a day. The anahaemin was given in a dose of $2 \mathrm{c.cm}$. daily throughout this three months. During the last month he received also proteolysed liver, $1 \mathrm{oz}$. daily. There was never any sign that these preparations had any effect on his condition. As each was proved ineffective, the blood picture was restored by blood transfusion and finally brought to 105 per cent. $\mathrm{Hb}(15 \cdot 4 \mathrm{~g}$. per 100 c.cm.), and 5,000,000 red blood cells on October 20, 1945.

The patient was discharged on October 27, 1945, with his $\mathrm{Hb}$ and red blood cells still at this level. Altogether 6 bottles (each $420 \mathrm{c.cm}$.) of whole blood and 9 (each of $500 \mathrm{c.cm}$.) of packed blood cells had been given. He continued to receive $2 \mathrm{c.cm}$. anahaemin daily under the care of his doctor. His condition rapidly deteriorated, as is shown by the estimation in Table 2 .

TABLE 2

\begin{tabular}{r|c|c}
\hline Date & Hb. & $\begin{array}{c}\text { Red blood } \\
\text { cells per } \\
\text { c.mm. }\end{array}$ \\
\hline 30.10 .45 & 100 per cent. $(14.7$ g. per 100 c.cm. $)$ & $4,600,000$ \\
7.11 .45 & 82 per cent. $(12.0$ g. per 100 c.cm. $)$ & $4,200,000$ \\
12.11 .45 & 65 per cent. $(9 \cdot 6$ g. per 100 c.cm. $)$ & $4,000,000$ \\
26.11 .45 & 40 per cent. $(5 \cdot 9$ g. per 100 c.cm.) & $2,300,000$ \\
\hline
\end{tabular}

He was readmitted to hospital on November 27, 1945.

\section{Condition on Readmission}

The patient now had a carbuncle in the left temporal region and a large deep abscess in the left deltoid muscle at the site of an injection. There were diffuse purpuric spots scattered over the limbs and trunk, but no ecchymoses. The liver was thought to be enlarged, with its edge three finger breadths below the costal margin. The spleen was not palpable, and there were no palpable lymph nodes. The other findings were the same as before.

\section{Developments Preceding Death}

On readmission the patient was given a bottle of packed blood cells (500 c.cm.), his deltoid abscess was 
incised, and systemic penicillin was administered. The abscess and carbuncle resolved. A series of blood transfusions was started, and he also received 'hepatex,' proteolysed liver, and vitamin preparations daily. On December 5, 1945, the coagulation time was two and a half minutes at room temperature (capillary method), and the bleeding time two minutes (Duke's method). A second sternal puncture was performed on December 21, 1945. The results are shown in Table 1, column B. No more purpuric spots appeared, and he seemed generally to improve until December 23, 1945, when a fairly severe epistaxis began, and continued as a steady ooze for two days. From this time his condition deteriorated rapidly.

On December 31, 1945, the blood picture was: Hb 45 per cent. (6.6 g. per 100 c.cm.); red blood cells $2,700,000$ per c.mm.; colour index 0.85 ; reticulocytes 12 per cent. of total red blood cells; total nucleated cells 9,000 per c.mm.; polymorphs 3 per cent.; lymphocytes 39 per cent.; monocytes 2 per cent.; eosinophils 1 per cent.; metamyelocytes 13 per cent.; myelocytes 4 per cent.; premyelocytes 6 per cent.; myeloblasts 6 per cent.; normoblasts 26 per cent. of total nucleated cells. The film showed marked anisocytosis. The red cells were a good colour, and only a very occasional polychromatic cell was seen. Platelets were extremely scanty.

On January 5, 1946, the blood picture was: Hb 52 per cent.; red blood cells $2,800,000$ per c.mm.; colour index 0.9 ; reticulocytes 3 per cent; total nucleated cells 14,000 per c.mm.; polymorphs 2 per cent.; lymphocytes 43 per cent.; monocytes 3 per cent.; basophils 1 per cent.; metamyelocytes 11 per cent.; myelocytes 20 per cent.; myeloblasts 8 per cent.; eosinophil myelocytes 3 per cent.; normoblasts 9 per cent. of total nucleated cells.

At about this time he developed a cellulitis of the pinna, which resolved with fomentation. A few days later he became dyspnoeic, and on January 9, 1946, complained of great thirst. The patient died at 7 a.m. on January 10, 1946. He had received 6 bottles (each $420 \mathrm{c.cm}$.) of fresh whole blood, 2 of stored blood, and 1 (500 c.cm.) of packed blood cells since readmission on November 27 , 1945.

\section{Post-Mortem Examination}

An autopsy was performed, as soon as permission had been obtained from the coroner, on January 11, 1946, twenty-eight hours after death. The body was not stored in a refrigerator, none being available.

\section{External Examination}

The body was of a rather thin, middle-aged man. There were a small number of petechiae and small ecchymoses on the neck, thorax, and abdomen. There was a large ecchymosis 2 in. in diameter under the skin of the right arm. Small very firm lymph nodes were palpable in the axillae and groins. Orifices were normal. Testes were in the scrotum and felt normal. Rigor mortis was present, and there were hypostases posteriorly.

\section{Internal Examination}

Cardiovascular System.-The pericardium was normal. The heart as a whole was slightly enlarged. Epicardium: there were a few small scattered petechiae over the surface of the right auricle and ventricle. The myocardium was pale and flabby, but not at all abnormally friable. Endocardium: there were two small petechiae on the interventricular septum, under the endocardium of the left ventricle; valves were all normal, and the chambers all dilated and filled with abundant ' chicken-fat ' clot.

The great veins were normal, and the pulmonary arteries completely filled with ' chicken-fat' clot. The aorta showed only slight atheroma. Other large arteries and coronary arteries also showed slight atheroma.

Respiratory System.-There were a number of avascular fibrous adhesions at the apex and mid-zone of the right side of the pleurae, but nothing else abnormal. The left side was normal. Both lungs were rather bulky, containing a slight excess of fluid. The lung parenchyma was a light brown colour with widely separated areas of anthracosis. There was an acute abscess, 1 inch in diameter, containing thick green pus in the upper lobe of the left lung in the mid-zone. A pure culture of coliform organisms was obtained from the pus. Larynx, trachea, and bronchi were normal; the bronchi contained brown frothy fluid (inhaled vomit).

Alimentary Systems.-The peritoneum was normal. The lips were pale. The mouth was edentulous, with upper and lower dentures, and the tongue showed several small submucous petechiae. The tonsils were slightly enlarged and covered with small areas of haemorrhage. The pharynx also showed several submucous haemorrhages, but was otherwise normal. The oesophagus was normal. The stomach was greatly distended with about 2 pints of opaque, brown, watery fluid, but was otherwise normal. The' pylorus and duodenum were normal. The small intestine was moderately distended with brown, watery fluid. The appendix was normal. The caecum and large intestine were normal, containing soft, dark brown faeces. The liver was almost twice normal size, and pale; the enlargement was symmetrical. The liver substance was pale brown throughout, and very firm to cut. The gall-bladder and bile ducts were normal, and there were no stones. The pancreas was normal.

Haemopoietic System.-The spleen was three to four times normal size, the capsule smooth, the pulp greyish red with no sign of normal pattern: it was rather soft, wet, and friable. Lymph nodes in all regions were slightly enlarged and firm, with greyish-red cut surfaces. The sternal marrow and that at the lower end of the right femur were both greyish-red and firm; no medullary tumours were present at these sites.

Genito-urinary System.-The kidneys were both about twice normal size; the capsules stripped easily; the renal parenchyma was very pale, almost white in places, with only small areas of normal pattern; complete medullary rays were replaced by areas of firm white tissue. Both pelves showed submucous haemorrhages. The kidneys were alike in every respect. The ureters, bladder, and prostate were normal. The testes were in the scrotum and felt normal. 
Endocrine System.-The sella turcica contained free blood, and the pituitary body was very soft, wet, and pale. The thyroid and adrenals were normal.

Nervous System.-The scalp and skull were normal. There was a small amount of haemorrhage in the subdural space over the vertex. The brain appeared normal in every respect. Table 3 gives the weights of organs.

TABLE 3

\begin{tabular}{l|c|c}
\hline \multicolumn{1}{c|}{ Organs } & Weights in g. & $\begin{array}{c}\text { Range of normal } \\
\text { (Ross, 1939) }\end{array}$ \\
\hline Brain & 1,340 & $1,250-1,275$ \\
Right lung & 940 & $480-680$ \\
Left lung & 1,020 & $420-600$ \\
Liver & 2,740 & $1,440-1,680$ \\
Spleen & 570 & $155-195$ \\
Heart & 398 & $250-280$ \\
Right kidney & 284 & 140 \\
Left kidney & 312 & 150 \\
\hline
\end{tabular}

\section{Principal Morbid Anatomical Findings}

The principal morbid anatomical findings were: (1) pallor and considerable enlargement of liver, spleen, and kidneys; (2) greyish-red firm bone marrow in sternum and lower end of femur; (3) slight generalized enlargement of lymph nodes; (4) acute abscess in the left lung; (5) dilated stomach containing 2 pints of fluid; (6) multiple petechial haemorrhages and small ecchymoses widely distributed throughout the body.

\section{Histology and Cytology of Tissues}

Blocks of tissue were taken from the following organs: heart; trachea, lungs (4); tonsil, pancreas, liver (2); spleen, cervical lymph nodes (right jugular chain) (2); bone marrow from sternum and lower end of right femur; kidneys (2); thyroid, adrenal, brain (2). All tissues removed at autopsy were cut into slices about $0.5 \mathrm{~cm}$. thick, and fixed immediately in Zenker's fluid (with 10 per cent. acetic acid). From each block sections were cut and stained respectively with: (a) Harris's haematoxylin and eosin; (b) Geimsa (Wolbach's method modified); (c) Weigert's haematoxylin and van Geisen's collagen stain; (d) Turnbull's stain for iron.

In every organ studied the blood vessels of all sizes were dilated, and almost every one was filled with a sheet of contiguous nucleated primitive blood cells, no mature erythrocytes being seen. In the brain (fig. 1), periadrenal tissues, and pancreas, however, there were a minority of vessels which each contained a mass of primitive blood cells filling one half of the lumen, the other half being occupied by erythrocytes and fibrin. A few vessels were seen in these situations which contained only mature erythrocytes. About 90 per cent. of the primitive blood cells were large (one and a half to twice the diameter of the erythrocytes seen in the same section), with large round or oval nuclei each showing a fine, open chromatin network with one or more nucleoli; and a faintly basophil cytoplasm, which in the majority of these cells showed no discrete granules. These cells were thought to be myeloblasts. There were numbers of similar cells which showed fine granularity of the cytoplasm, and a few had indented nuclei (premyelocytes and myelocytes). Smaller numbers of cells were seen with smaller round or oval nuclei, a much denser and closer mesh chromatin network, and usually a darker, basophil, non-granular cytoplasm: these were interpreted as erythroblasts. Recognizable normoblasts with pyknotic nuclei were seen in small numbers, and occasional eosinophil myelocytes also.

Large interstitial collections of primitive blood cells, mostly of the myeloid series, were seen in the sections of lungs, tonsil, liver, lymph nodes, spleen, kidneys, and peri-adrenal tissues. In the spleen (fig. 2), lymph nodes (fig. 3), and tonsil (fig. 4), these collections were massive and formed the main bulk of the tissue in the section, but some remaining lymphoid tissue was still seen, in the spleen around the central arterioles, and in the lymph nodes and tonsil as widely separated small lymphoid follicles. In many places in the kidney areas of primitive blood cells widely separated the renal elements; similar areas were seen in the lungs and in the periportal regions of the liver. In all these sites the overwhelmingly predominant cell was the myeloblast, with smaller numbers of myelocytes, erythroblasts, and eosinophil myelocytes. Erythroblasts were more numerous in the tonsil than elsewhere. Mitoses were seen in fair numbers in the cell masses in the lymph nodes and kidney, and the latter showed also small numbers of mononuclear giant cells.

There was massive necrosis of the parenchymal cells of the liver (fig. 5) and of the renal (fig. 6) convoluted tubules. The liver cells showed only faint outlines of a nucleus, or none at all (karyolysis): their cytoplasm was mostly pink and coarsely granular (haematoxylin and eosin stain), containing some fine yellow pigment granules and showing a trace of fine blue granularity with Turnbull's iron stain. The convoluted tubules of the kidney all showed almost complete karyolysis, only traces of cell nuclei being seen. The cells were coarsely granular, with no definite margins. The lumina of the great majority of the convoluted tubules were obliterated by granular epithelial-cell débris.

The loops of Henle and collecting tubules were much better preserved. The cell nuclei stained normally, but their cytoplasm was granular and the cells had shrunk away from their basement membranes. The glomerular capillary tufts were plump and rounded, with a variable degree of segmentation. The capsular spaces all contained desquamated capsular epithelium.

The heart muscle showed severe fragmentation of the muscle fibres. There was no sign of excessive siderosis. in any of the tissues studied. The sternal bone marrow (fig. 7) and that from the lower end of the right femur (fig. 8) presented identical histological features. Both showed the greatest possible degree of hyperplasia, with sheets of contiguous primitive blood cells completely filling the spaces between the bone trabeculae (except for narrow, clear, peripheral zones apparently formed by retraction of the cell masses). There was no sign of fatty, fibrous, or other non-haemopoietic tissue in these. 
spaces in any of the marrow sections. The haemopoietic tissue showed no obvious qualitative deviation from the picture seen in the sternal puncture smears.

\section{Discussion}

The case here described had a history of 5 years' daily exposure to benzene, followed by 2 years 8 months of intermittent exposure. At the end of this time the man became ill with a severe refractory anaemia, accompanied by a diminution in numbers of the leucocytes and platelets, and with variable numbers of primitive cells of both red- and white-cell series in the circulation.

Sternal puncture showed a hyperplastic marrow with erythroid elements predominating, and failure of maturation of both the erythroid and myeloid series of cells.

At autopsy the bone-marrow hyperplasia was confirmed, and histological studies showed extensive areas of both myeloid and erythroid haemopoiesis in the spleen, lymph nodes, tonsils, kidney, liver, lung, and peri-adrenal tissues. The histological picture was not that of a leukaemia, the primitive cells being far too heterogeneous, and the follicular structure of the lymphoid organs being too well preserved. It corresponded more closely with the histology of some of the organs described by Mallory and others (1939) in their cases of benzene poisoning; and even more closely with that described by Jackson and others (1940) as characteristic of the condition they termed 'agnogenic myeloid metaplasia,' some cases of which have been shown to follow prolonged exposure to benzene.

The evidence that the case here described was due to benzene poisoning is, as with all others so diagnosed, only circumstantial, but, when considered in relation to the other cases quoted from the literature, $t$ would appear to be convincing.

The fact that the patient became ill during a period of reduced benzene exposure is not evidence against the idea that benzene was the causal agent. Smith (1943) described a case of fatal benzene poisoning with its onset in the fourth year after the last exposure, and he found 5 earlier cases in the literature where an interval elapsed between the last exposure and the onset of symptoms: in 2 of these the interval was ten years. The extreme individual variations in the relation between intensity and period of exposure, and the clinical consequences are well known.

Several features in the microscopical findings merit discussion. In the first place, the identity of the various primitive blood cells in the tissues and vessels in material fixed twenty-eight hours after death is not easy to establish with certainty. In particular, the most numerous cells, which have been interpreted as myeloblasts for the reasons stated, may in fact have been 'blast' cells of another kind. That they were very early bloodforming cells of one sort or another seems beyond reasonable doubt.

The appearances in the blood vessels everywhere suggested a terminal outpouring of primitive blood cells in enormous numbers from the tissues into the circulation, until they greatly outnumbered the circulating erythrocytes, followed by a post-mortem settling of the nucleated cells below the erythrocytes in some of the vessels. Some suggestion of the beginning of this process may be seen in the nucleated cell counts, which rose from 3,000 in July, 1945, to 9,000 on December 31,1945 , and to 14,000 on January 5, 1946, the increase being due mainly to the appearance of increasing numbers of primitive cells of both series. That there was time for settling of the cells before clotting occurred is shown by the presence of ' chicken-fat' clot in the heart.

The gross degenerative and necrotic changes in the liver, kidney, and myocardium were too severe and too extensive to have preceded death by more than a few hours. It is suggested that they were the result of a terminal anoxia produced by the rapid outpouring of primitive blood cells into the circulation, leading to an increased blood viscosity, diminished blood flow, and a dilution of the already reduced numbers of erythrocytes.

\section{Summary}

The clinical and pathological condition of a man who developed an intractable anæmia, leucopenia, and thrombocytopenia following many years' exposure to benzene solvents is described.

He proved to have a grossly hyperplastic bone marrow, with extensive areas of extramedullary hæmopoiesis.

The literature which suggests that this may be a common reaction to benzene exposure is reviewed.

\footnotetext{
The author wishes to express thanks to Dr. R. G. Howat for access to the clinical notes, to Mr. S. F. Moores for technical assistance, and to Mr. F. A. Murray, who prepared the photomicrographs.

\section{REFERENCES}

Blumer, G. (1905). Johns Hopk. Hosp. Bull., 16, 127 Hamilton, A. (1931). Arch. Pathol., 11, 434, 601

Jackson, H., Jr., Parker, F., Jr., and Lemon, H. M. (1940). New Jackson, H., Jr., Parker, F., 98 .

Mallory, T. B., Gall, E. A., and Brickley, W. J. (1939). J. industr. Hyg., 21, 355 .

Hyg., 21, 355.
Rawson, R., Parker, F., Jr., and Jackson, H., Jr. (1941). Science, 93, 541 .

Rhoades, C. P., and Miller, D. K. (1938). Arch. Pathol., 26, 648.

Ross, J. M. (1939) Post-mortem Appearances, London.

Santesson, C. G. (1897). Arch. Hyg., 31, 336.

Selling, L. (1910). Johns Hopk. Hosp. Bull., 21, 33.

(1916). Johns Hopk. Hosp. Rep., 17, 83.

Smith, A. R. (1943). Industr. Bull., 22, 329.

Thompson, W. P., Richter, M. N., and Edsall, K. S. (1934). Amer. J. med. Sci., 187, 77 .
} 


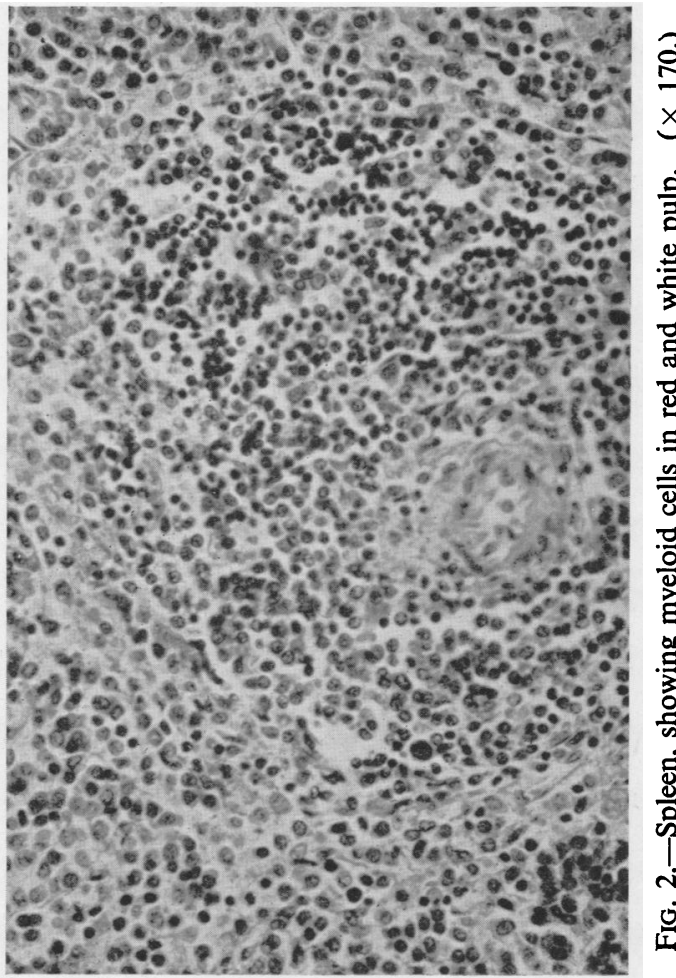

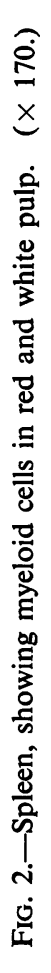
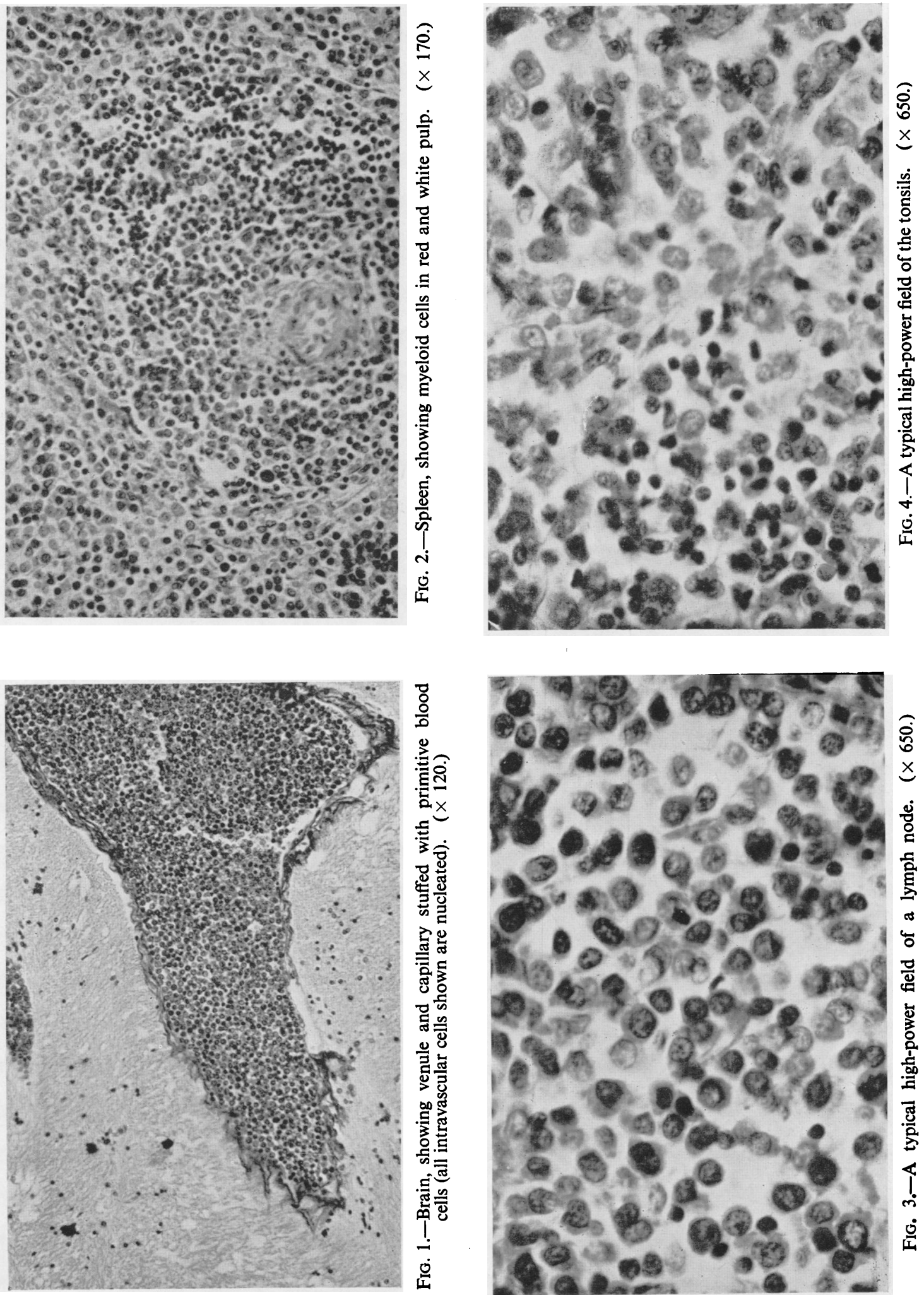

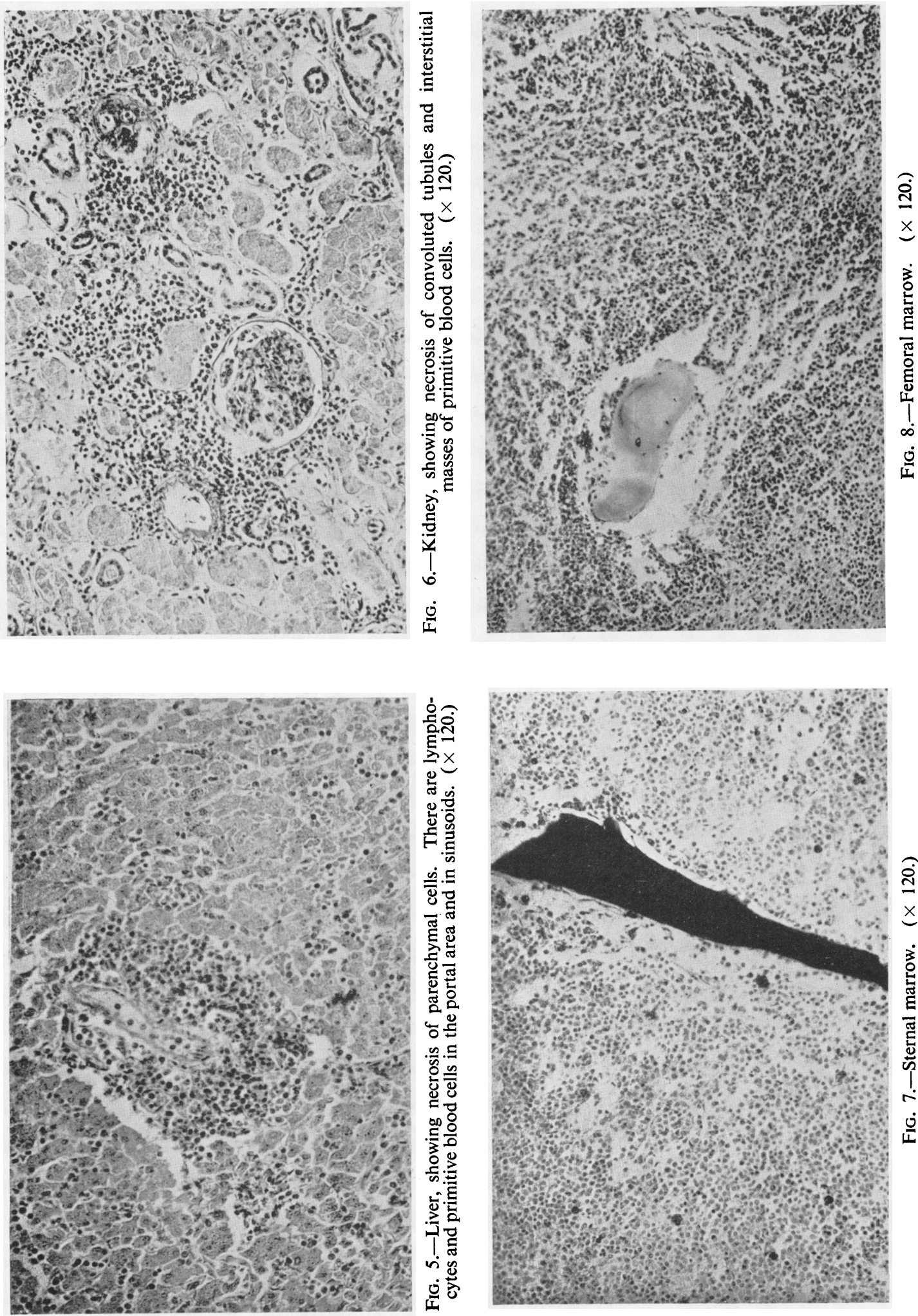